\title{
Simple left atrial reduction in giant left atrium accompanying mitral stenosis
}

\author{
Prosta redukcja wymiaru olbrzymiego lewego przedsionka \\ towarzyszącego stenozie mitralnej
}

\author{
Ahmet Coşkun Özdemir ${ }^{1}$, Bilgin Emrecan² \\ ${ }^{1}$ Department of Cardiovascular Surgery, Medical Faculty, Trakya University, Turkey \\ ${ }^{2}$ Department of Cardiovascular Surgery, Medical Faculty, Pamukkale University, Turkey \\ Kardiochirurgia i Torakochirurgia Polska 2012; 9 (4): 474-476
}

\begin{abstract}
A patient with giant left atrium due to rheumatic mitral vaIve disease with spontaneous echocardiographic contrast in the giant left atrium is presented in this case report. The left atrial diameter reduction from dimensions of $118 \times 104 \mathrm{~mm}$ to $80 \times 77 \mathrm{~mm}$ was attained by excision of two-centimeter wide strips of left atrium on both sides by widely plicating the left atrial appendage from the inside with running polypropylene sutures. Spontaneous echocardiographic contrast disappeared in the postoperative echocardiographic control. The patient had uneventful recovery in the postoperative period and was discharged on the fifth day after the operation.

Key words: heart atria, surgery.
\end{abstract}

\section{Introduction}

Giant left atrium (GLA) refers to left atrial dimensions exceeding $80 \mathrm{~mm}$. It is seen in mitral valve disease, left ventricular failure, chronic atrial fibrillation, and left-to-right shunts such as those occurring with patent ductus arteriosus and ventricular septal defects [1]. Rheumatic pancarditis has also been postulated for atrial enlargement, which is easily dilated when filled by mitral regurgitation [2].

We in this case report present a patient with GLA due to mitral valve disease who was surgically treated.

\section{Case report}

A 61-year-old woman with shortness of breath (NYHA class 3) was admitted to the outpatient clinic. She had been suggested mitral valve surgery several years before yet she had not accepted. She had dyspnea, orthopnea, paroxysmal nocturnal dyspnea and dysphagia on admission. She was cachectic and weighed $35 \mathrm{~kg}$. Her blood pressure was

\section{Streszczenie}

W pracy przedstawiono przypadek pacjenta z olbrzymim lewym przedsionkiem w przebiegu reumatycznej choroby zastawki mitralnej z obrazem samokontrastującej się krwi w badaniu echokardiograficznym. Zmniejszenie lewego przedsionka z wymiaru $118 \times 104 \mathrm{~mm}$ do $80 \times 77 \mathrm{~mm}$ osiągnięto poprzez obustronne wycięcie dwucentymetrowych pasków lewego przedsionka i wykonanie od wewnątrz plikacji uszka przy użyciu szwów polipropylenowych. W pozabiegowym badaniu echokardiograficznym nie stwierdzono obrazu samokontrastującej się krwi. Okres pooperacyjny przebiegał bez powikłań, a chorego wypisano ze szpitala w 5 . dobie po zabiegu. Słowa kluczowe: przedsionki serca, operacja.

110/60 mm Hg. She had systolic murmur in the mitral area, diastolic murmur on the mesocardiac area, and fine rales on inspiration on physical examination. She also had venous distension in the jugular veins.

The chest X-ray demonstrated increased cardiothoracic index. She had atrial fibrillation with a rapid ventricular response on electrocardiography. On echocardiography, she had severe rheumatic mitral valve stenosis with a mitral valve area of $0.6 \mathrm{~cm}^{2}$, a peak gradient of $25 \mathrm{~mm}$ $\mathrm{Hg}$, a mean gradient of $11 \mathrm{~mm} \mathrm{Hg}$, and moderate degree mitral valve regurgitation. The mitral valve was thick and fibrotic. Pulmonary artery pressure was $45 \mathrm{~mm} \mathrm{Hg}$. Left ventricular end diastolic and end systolic dimensions were $41 \mathrm{~mm}, 27 \mathrm{~mm}$, respectively. Left ventricular ejection fraction was $60 \%$. There was also severe tricuspid valve regurgitation. The aortic valve also had moderate degree regurgitation. She had a giant left atrium with the dimensions of $118 \times 104 \mathrm{~mm}$. She also had spontaneous echocardiographic contrast even showing stasis of the blood flow in

Address for correspondence: Bilgin Emrecan, Yunus Emre, cad. No: 83/5 Kınıklı 20070, Denizli, Turkey, tel. +902582666768, fax +902582666001, e-mail: bilginemrecan@yahoo.com 
the left atrium (Fig. 1A). Cardiac catheterization was performed, showing normal coronary arteries.

Standard general anesthetic and cardiopulmonary bypass strategies were used for the operation. The left atrium was occupying most of the mediastinum (Fig. 2A). Left atriotomy was done from the interatrial groove. The mitral valve was replaced with a $25 \mathrm{~mm}$ mitral mechanical prosthesis. The posterior leaflet was preserved. The aortic valve was also thick and fibrotic and it was also replaced with a $19 \mathrm{~mm}$ aortic mechanical prosthesis. The left atrial diameter was reduced by widely plicating the left atrial appendage from the inside with running polypropylene sutures. The atriotomy incision was lengthened on both ends. Two-centimeter wide strips of left atrium on both sides of the atriotomy were excised from the left atrial wall (Fig. 3). The left atriotomy was closed by wide pitting running sutures in order to further reduce the left atrial diameter (Fig. 2B). After deairing the left heart, the cross-clamp was taken. The tricuspid valve was approached from the right atriotomy on beating heart. Modified DeVega annuloplasty was done to the tricuspid valve and the right atriotomy was closed. She had an uneventful recovery in the postoperative period. She had sinus rhythm on the second day of surgery which was maintained in the postoperative period. She was discharged on the fifth day after the operation. The left atrial dimensions were $80 \times 77 \mathrm{~mm}$ fifteen months after the surgery. She had mild degree tricuspid regurgitation on postoperative echocardiography. Spontaneous echocardiographic contrast disappeared in the postoperative echocardiographic control (Fig. 1B).

\section{Discussion}

This case is one of the largest left atria that has been reported in the literature. The atrial reductive surgery done in this case was simple and effective. It is not simpler than the left atrial volume reduction surgery by triangular resections of the atrial wall suggested by Sinatra et al. [3]. Even partial heart autotransplantation was used in a mitral and tricuspid valve operation to treat giant left atrium [4]. Left atrial dilatation may even be complicating for pulmonary function. Some authors have anesthetized the patients with negative pressure ventilation before connecting to
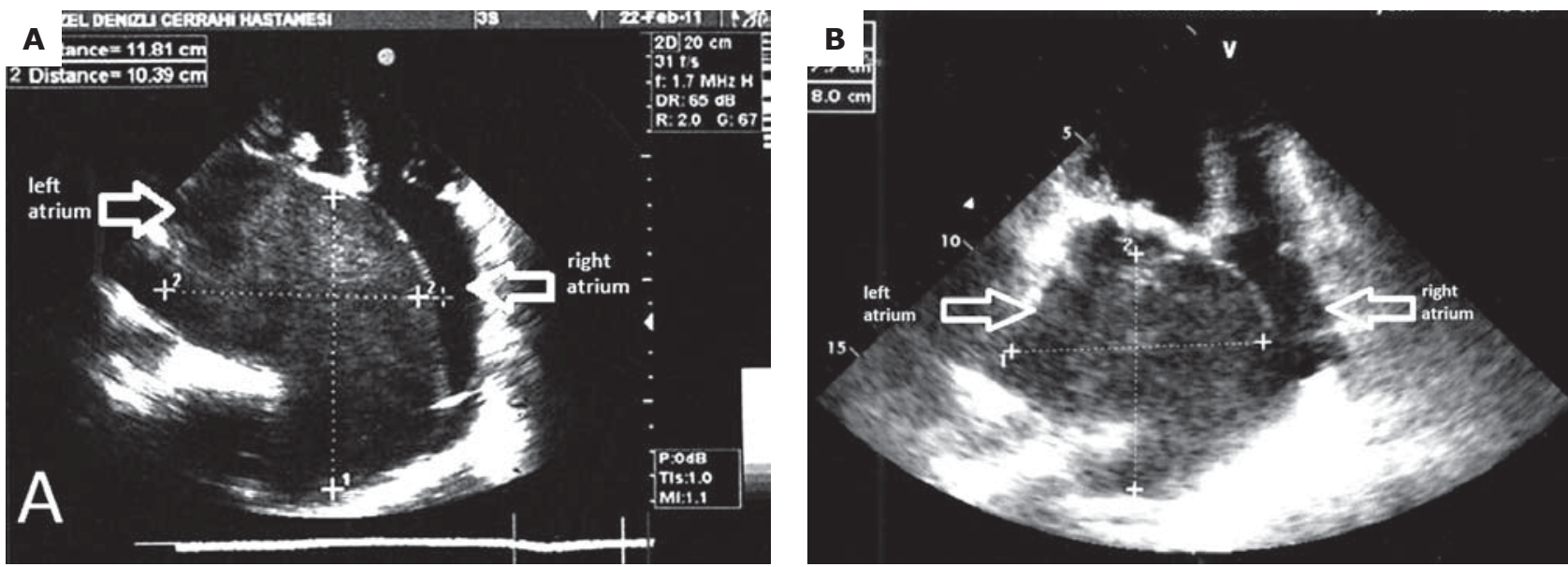

Fig. 1A-B. Echocardiography showing spontaneous echocardiographic contrast in the left atrium (A). Spontaneous echocardiographic contrast disappeared after the operation (B)
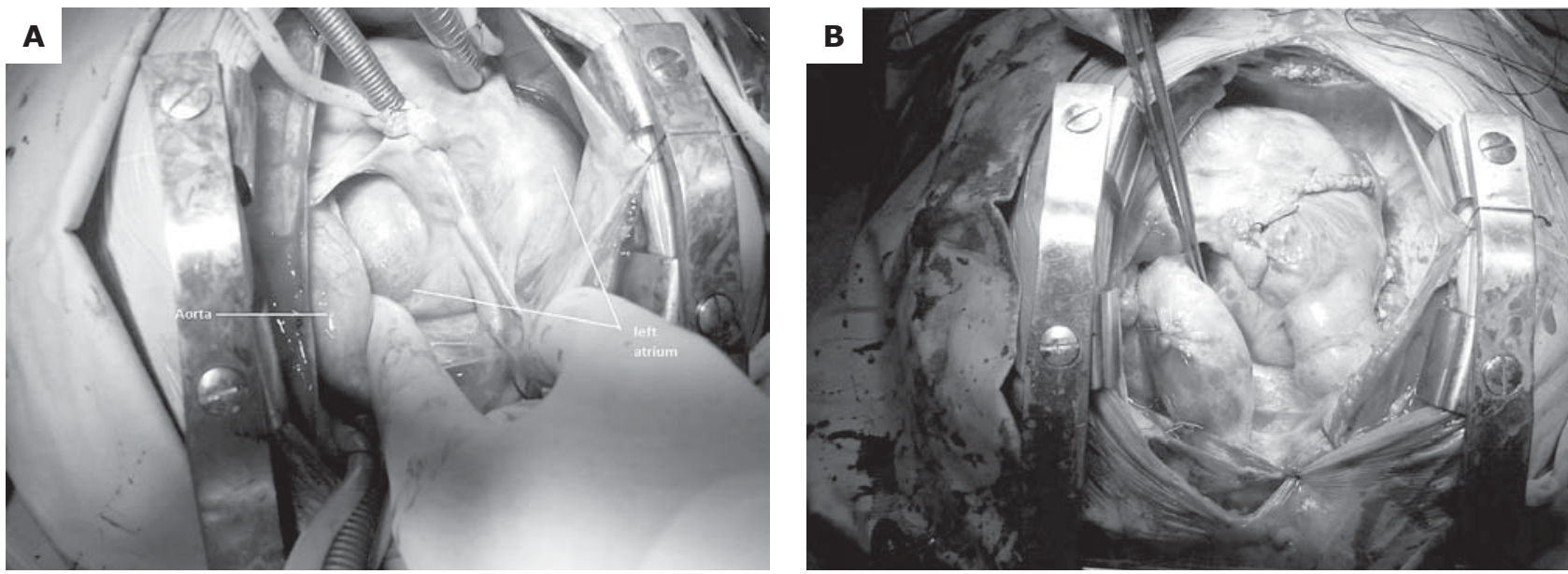

Fig. 2A-B. Operative view before left atrial diameter reduction (A). Operative view after left atrial diameter reduction (B) 

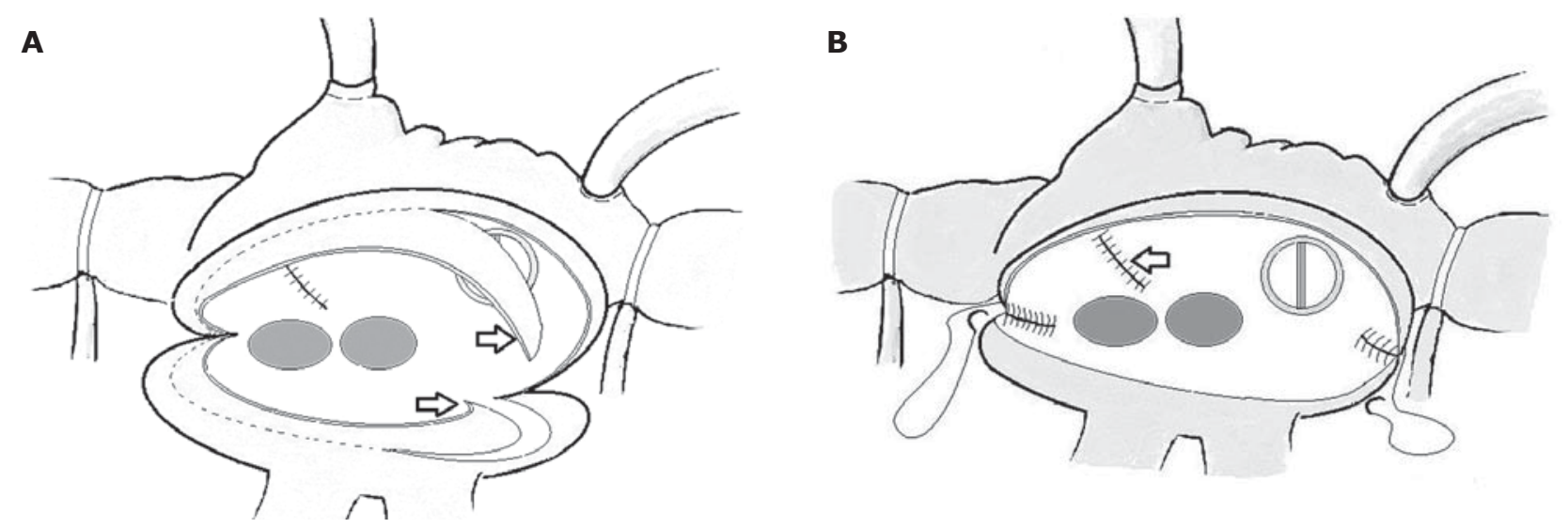

Fig. 3A-B. Illustration showing left atrial reduction from the surgeon's point of view. The atriotomy incision lengthened at both ends. The arrows indicate resection of wide strips on both sides of atriotomy (A). The left atriotomy closed by wide pitting running sutures. The arrow indicates plicated left atrial appendage (B)

the cardiopulmonary bypass circuit as a bridge to cardiopulmonary bypass in certain cases [5].

Patients usually present with complaints of shortness of breath [5] or dysphagia [6]. Giant left atrium also increases the thromboembolic risk, despite anticoagulant therapy [6]. Thromboembolic risk may be due to stasis of the left atrial blood flow as seen in the present case. We saw disappearance of the spontaneous echocardiographic contrast after the operation. Asymptomatic patients with huge left atria have also been reported [7].

We suggest simple plication of the left atrium as in our case, which is effective and fast.

\section{Disclosure statement}

The authors do not have a conflict of interest. The authors have no financial or other interest in the manufacture or distribution of any materials that were used.

\section{Acknowledgement}

The authors were working in Özel Denizli Cerrahi Hospital, Denizli, Turkey during the operation in the described case.

\section{Literature}

1. Fasseas $P$, Lee-Dorn R, Sokil AB, VanDecker W. Giant left atrium. Tex Heart Inst J 2001; 28: 158-159.

2. Hurst W. Memories of patients with a giant left atrium. Circulation 2001; 104: 2630-2631.

3. Sinatra R, Pulitani I, Antonazzo A, Melina G. A novel technique for giant left atrium reduction, Eur J Cardiothorac Surg 2001; 20: 412-414.

4. Lessana A, Scorsin M, Scheublé C, Raffoul R, Rescigno G. Effective reduction of a giant left atrium by partial autotransplantation. Ann Thorac Surg 1999; 67: 1164-1165.

5. Onat A, Ugur M, Cicek G, Ayhan E, Dogan Y, Kaya K, Can G. A giant left atrium. Türk Kardiyol Dern Arş 2010; 38: 223.

6. Kachel E, Schaff HV, Moussa F, Preisman S, Ranani E, Sternik L. Giant left atrium needed negative pressure ventilation. Ann Thorac Surg 2010; 89: 269-271.

7. Funk M, Perez M, Santana O. Asymptomatic giant left atrium. Clin Cardiol 2010; 33: E104-E105. 